\title{
Vegetable soybean: Seed composition and production research
}

\author{
Qiuying Zhang, ${ }^{1}$ Yansheng $\mathrm{Li}^{,}{ }^{2}$ Kit L. Chin, ${ }^{3}$ Yadong $\mathbf{Q i}^{3}$ \\ ${ }^{1}$ Key Laboratory of Molecular Breeding and Design, Northeast Institute of Geography and Agroecology, \\ Chinese Academy of Sciences, Harbin; ${ }^{2}$ Key Laboratory of Mollisols Agroecology, Northeast Institute of \\ Geography and Agroecology, Chinese Academy of Sciences, Harbin, China; ${ }^{3}$ Agricultural Research \& \\ Extension Center, Southern University, Baton Rouge, LA, USA
}

\begin{abstract}
Vegetable soybean (edamame) [Glycine max (L.) Merr.] is a low input, high nutritional value, short crop cycle and soil-enriching profitable crop. It offers quick economic return and provides health benefits to the consumers. The market demand for edamame has begun to flourish and expand dramatically in recent decades due to increased awareness of nutritional properties, and the change in life styles towards healthier food. This article highlighted the importance of edamame as a nutraceutical and functional food-grade produce, summarised the research advances in seed composition and their roles, cultivar selection and crop establishment, planting date and fertilisation, weed management and harvesting. Current production problem of extensive labour at harvest and future research challenges in improving crop establishment, developing cultivars competitive to weed and resistant to pest insects/diseases, assessing biological activities of edamame elemental and phytochemical properties on cancer cell inhibition, and developing organic production system were also proposed with aims of enhancing farm profitability and expanding opportunities for extensive use of edamame.
\end{abstract}

Correspondence: Qiuying Zhang, Key Laboratory of Mollisols Agroecology, Northeast Institute of Geography and Agroecology, Chinese Academy of Sciences, Harbin 150081, China.

Tel: +86-451-86691320.

E-mail: zhangqiuying@iga.ac.cn

Key words: Edamame; Chemical properties; Sowing; Fertilisation; Market prospect.

Acknowledgements: this research is partially funded by National Natural Science Foundation of China (grant No.41471241), and Major Program of National Science and Technology of China (2016YFD0102105, 2016YFD0100201).

Received for publication: 17 November 2016.

Revision received: 24 February 2017.

Accepted for publication: 9 April 2017.

CC Copyright Q. Zhang et al., 2017

Licensee PAGEPress, Italy

Italian Journal of Agronomy 2017; 12:872

doi:10.4081/ija.2017.872

This article is distributed under the terms of the Creative Commons Attribution Noncommercial License (by-nc 4.0) which permits any noncommercial use, distribution, and reproduction in any medium, provided the original author(s) and source are credited.

\section{Introduction}

Vegetable soybean (edamame) [Glycine max (L.) Merr.] is harvested at full-seed development stage with a larger, sweet, nutty, and mild flavour seed (Zhang et al., 2015). Vegetable soybean was known for its nutritional and medicinal values and it was consumed as a vegetable in the Far East as early as the second century BCE (Shanmugasundaram, 2001; Shurtleff and Aoyagi, 2009). While edamame is an excellent source of plant-based protein, it is also a complete protein, containing all the essential amino acids and higher isoflavones as well as sucrose in the human diet (Velasquez and Bhathena, 2007; Li et al., 2012). Frozen edamame can be used as a weight-loss ingredient to lessen intake of food. The lower trypsin-inhibitor levels and lower cell density, making it more digestible than grain-type soybeans with only a shorter cooking time and cooking edamame has the benefit of doubling the iron bio-availability (Chadha and Oluoch, 2004). Considered as a functional food, edamame affects any identified body function in a positive manner, and it could be available in different forms or under different names (Hasler, 1996; Mimura et al., 2007).

Edamame can substitute for green peas or lima beans in any recipe (Miles et al., 2000). The growing season of vegetable soybean is shorter than grain-type soybean because the crop is harvested at an immature stage, i.e. R6 (full seed stage) versus R8 (full maturity stage) (Zhang et al., 2010; Sam et al., 2012). The short growth duration allows edamame to fit into narrow windows in a crop rotation (Shanmugansundaram and Yan, 2004). The plant produces high quality nutritive fresh beans, while the green plant stocks can be used as livestock feed or green manure to incorporate into the soil to enhance soil fertility for subsequent crops in 65-75 days.

As a legume crop, vegetable soybean is a low input, soilenriching crop that can help farmers to minimise insect and disease resistance in the farm, and will have long-term effect for agricultural sustainability as well. The successful cultivation of vegetable soybean for commercial market can potentially enhance small farm profitability and reduce dependency on importation to given countries (Zhang et al., 2013b; Ogles et al., 2016). Economically, edamame can become an export commodity under the international trade (Zhang et al., 2013b; Schnitkey, 2015).

The growing popularity of edamame as a healthy snack food has led to increased interest in edamame production from soybean producers, and begun to flourish and expand dramatically in recent decades due to increased awareness of nutritional properties, and the change in life styles towards healthier food as well, which created a market boom across many countries (Carson et al., 2011; Shockley et al., 2011; Soyfoods, 2014). For example, the importation of frozen edamame in US has increased from 300500 tons per year in 1980 s to 10,000 tons in 2000 , and to 25,000 
tons in 2005, and a four-fold increase in consumption of vegetable soybean in the U.S between 2000 and 2008 (Sams et al., 2012). Edamame is currently the second most consumed soy food, behind soymilk, in the United States (Soyfoods, 2014). In 2013, it was estimated that the United States consumed between 22,700 to $27,270 \mathrm{Mg}$ of edamame (Nuss, 2013). This increased demand is expected to continue as consumers look for healthier, lower cost sources of protein to add to their diet. Moreover, the United Soybean Board forecasts vegetable soybean will outgrow other soy products by the year 2020 due to ethnic population growth and health-conscious populace (Shockley et al., 2011). The current edamame imports are valued at more than $\$ 9$ million (Dong et al., 2014). A premium on average economic return per hectare, ranging from $\$ 18$ to $\$ 589 / \mathrm{t}$ above the market price of commodity soybean (Carter and Wilson, 1998) and three fold greater than grain-type soybean from vegetable soybean (Zhang et al., 2013b), have been reported.

In response to this increasing demand, growers, plant breeders, and food processors have grown increasingly interested in the production of edamame as commodity soybean prices are projected to decrease (Schnitkey, 2015), which prompted food processers and packagers to look to local sources to fill the expanding need.

Fueled in part by increasing consumer interest in the product itself and in internationally grown products in particular, fully understanding the significance and production practices as well as obstacles is needed to evaluate this crop in relation to economic production.

This paper summarised the merits of seed composition and their roles, discussed the development of production related research, with an aim to fully exploit this profitable crop for researchers, growers, and food processors.

\section{Seed compositions of vegetable soybean}

The protein and oil contents are the main quality traits of vegetable soybean and are valued by edamame breeders. The protein content of vegetable soybean was 56\% higher than green peas $(P$. sativum) (Masuda, 1991). Rao et al. (2002) reported that protein and oil content of fresh seed vegetable soybean ranged from 33 to $39 \%$ and 13 to $16 \%$, respectively. In developed countries, vegetable soybean varieties with lower oil percentage and relatively higher protein content are more popular among young people who seek healthy diets (Brar and Cater, 1993). Saldivar et al. (2011) stated that vegetable soybean seed with more than $45 \%$ protein and seed oil of less than $18 \%$ are acceptable. Abe et al. (2005) confirmed that the levels of $\beta$-conglycicin- $\beta$-subunits and sucrose binding proteins of vegetable-type soybean were about 70 and $75 \%$, respectively, in comparison with those of grain-type cultivars. These quantitatively reduced levels of $7 \mathrm{~s}$ globulin lead to possible increase of $11 \mathrm{~s} / 7 \mathrm{~s}$ ratio and then preferable for nutrition value.

Carbohydrate is the predominant component ranging from 42.4 to $48.1 \%$, followed by protein $(34.2-35.4 \%)$, oil (13.1-17.5 \%) and ash (4.21-4.88\%) for three vegetable soybean varieties grown in Virginia. The major sugars in the beans are sucrose (5.94-12.2\%) and fructose (1.61-2.31\%) (Xu et al., 2015). The total soluble sugar content ranged from $6.0 \%$ to $7.4 \%$ in a four-year study in Taiwan (Tsou and Hong, 1991) and $7.5 \%$ to $12.5 \%$ during a three-year study in China (Zhang et al., 2006), while sucrose content constituted $71 \%$ of total soluble sugar (Li et al., 2012). The mean values in seed protein, oil, total soluble sugar (TSS) and sucrose of veg- etable soybean varieties (lines) were 420, 186, 60 and $43 \mathrm{mg} \mathrm{g}^{-1}$, respectively (Li et al., 2012). A significant positive correlation between seed sugar and oil contents has been reported, and it seems to be a challenging task to develop a high sucrose vegetable soybean with high protein but low oil content. However, the results reported by other researchers showed a negative relationship between sugar and oil. For example, Shanmugasundaram et al. (2001) reported that the correlation coefficient between sugar and oil content was -0.50 , whereas between sugar and protein content was -0.15 but significant only in 6 out of 20 entries. Negative correlations were found between protein and TSS $(\mathrm{r}=-0.52)$, protein and sucrose ( $\mathrm{r}=-0.43)$ (Li et al., 2012). They further indicated that every $10 \mathrm{mg} \cdot \mathrm{g}^{-1}$ increase in seed protein was accompanied by 4.3 $\mathrm{mg} \cdot \mathrm{g}^{-1}$ decrease in sucrose. No significant correlation $(\mathrm{P}>0.05)$ was found between oil and TSS, and oil and sucrose. This means that it is feasible to develop vegetable soybean cultivars with higher sucrose, lower oil content without reduced protein content.

Proximate analysis of seed nutritional composition indicated that vegetable soybean has superior nutritional content than green peas (Johnson et al., 1999; Masuda, 1991). Vegetable soybeans contain about 50 percent more isoflavones than mature soybean seeds (Koes et al., 2005; Wu et al., 2004). The content of isoflavones was 78 to $220 \mu \mathrm{g} / \mathrm{g}$ dried seed) and tocopherols (vitamin E) ranged from 84 to $128 \mu \mathrm{g} / \mathrm{g}$ dry seed (Mohamed et al., 2001), while the contents of the individual isoflavones were reported to differ depending on soybean variety and cultivation conditions (Lee et al., 2003). Kimet al. (2007) found a total average concentration of isoflavone was $2887 \mu \mathrm{g} \mathrm{g}^{-1}$ in embryo, $5751 \mu \mathrm{g} \mathrm{g}^{-1}$ in whole seed, $325 \mu \mathrm{g} \mathrm{g}^{-1}$ in cotyledon, and $33 \mu \mathrm{g} \mathrm{g}^{-1}$ in seed coat. Isoflavones accumulated in the order of malonylglycoside, glycoside, acetylglycoside, and aglycon, among which malonylglycoside was the most abundant form ranging from 66 to $79 \%$ of the total isoflavone content in all three tissues.

The calorific value (energy) of vegetable soybean is about 6 times higher than the one of green peas. Vegetable soybean contains $60 \%$ more calcium, and twice the amount of phosphorous and potassium than green peas. The sodium and carotene content of vegetable soybean is about one-third that of green peas and has similar quantities of iron, vitamins $\mathrm{B}_{1}$ and $\mathrm{B}_{2}$. Besides, vegetable soybean is also rich in ascorbic acid but low in niacin (Masuda, 1991; Zhang and Kyei-Boahen, 2007).

Therefore, edamame is one of only a handful of plant-based foods that contains all the essential amino acids such as lysine and tryptophan lacking in rice and wheat, high content of sugar, more minerals and is the best source of secondary metabolites.

\section{Roles of seed chemical compounds}

The major chemical compounds related to soybean seed taste are sucrose, glutamic acid and alanine (Masuda, 1991; Li et al., 2012). A combination of ascorbic acid, sucrose, glutamic acid, and alanine make vegetable soybeans tasty. Sugar and volatile component are classified as the main chemical substances, which affect the eating quality of fruit (Jouquand et al., 2008). Sucrose is the basic component responsible for sweetness. However, its sweetness may be enhanced during the process of boiling clue to the generation of another sugar, maltose. Maltose exhibit 0.4 times the sweetness strength of sucrose, and has more refreshing aftertaste (Masuda, 2004). The cumulative contribution of sucrose, fructose + glucose, raffinose, stachyose, protein, free amino acid, and oil to edible quality was $67.8 \%$, and edible quality score was positively 
related to sucrose content, but negatively related to protein content (Zhang et al., 2015). Shanmugasundaram et al. (2001) reported that the cultivars of vegetable soybean with higher sucrose level were more popular than the cultivars with low sucrose in Japan. Unacceptable traits like bitterness, astringency and off-flavors have been attributed to saponins and isoflavins, whereas cis-jasmone, and (Z)-3-hexenyl-acetate have been reported to confer desirable flavor (Masuda, 1991).

Monounsaturated fatty acids constitute a greater fraction of lipids in fresh green seeds (Johnson et al., 1999), which makes vegetable soybean a nutritious snack. Secondary metabolites such as phenolic compounds, isoflavones, saponins, and phytic acids outstandingly serve as a healthy dietary supplement. In plants, these compounds are known to play various roles in being repellent to herbivorous insects and animals, protection against UV light and phytopathogens, signal transduction during nodulation, and attraction of pollinating animals (Reuber et al., 1996; Koes et al., 2005).

Soybean isoflavone has a phenolic structure similar to estrogen known as a phytoestrogen and provides a natural alternative to the use of postmenopausal hormone replacement therapy. Isoflavones and saponins have been implicated in potential health benefits related to age-related and hormone dependent diseases, including breast and ovarian cancer, menopausal symptoms, mammary, cardiovascular disease, and osteoporosis (Anderson et al., 1995; Yoshiki et al., 1998; Setchell and Cassidy, 1999; Kulling et al., 2002; Messina and Wu, 2009; Keatinge et al., 2011). There is some evidence, mostly in animal studies, that soya saponins can lessen the rate of lipid peroxidation in blood vessels, as well as absorption of cholesterol from GI tract, and increase excretion of fecal bile acids. All these events would be expected to contribute to decrease the risk of cardiovascular disease. Moreover, genistein (an isoflavone phytonutrient in soy) can increase the activity of a tumor suppressor protein called p53; when p53 becomes more active, it can help trigger programmed cell death (apoptosis) in cancer cells, and it also helps to trigger cell cycle arrest (stop ongoing cancer cell activity). Genistein has also been reported to block the activity of protein kinases in a way that it can help slowing tumor formation, especially in the case of breast and prostate cancer (Adlercreutz, 2002; Messina, 2001; Butler et al., 2010; Hara et al., 2012).

In general, sucrose plays an irreplaceable role in sweetness. As powerful antioxidants, isoflavones can reduce the incidence of certain cancers and cardiovascular disease. Future research needs to examine the genetic and physiological basis of higher sucrose content genotypes, and to understand possible interactions of secondary metabolites or compounds in preventing the generation of harmful products to human. The latter might be complex and challenging.

\section{Cultivar selection and crop establishment}

For edamame production to become commercially viable, growers need adapted cultivars that will perform well in their environment. Edamame cultivars from different maturity groups will bloom at different times based on the latitude in which they are grown and the subsequent daylength (Cregan and Hartwig, 1984). Indeed, cultivars suitable for production in Washington State may not be suitable for production in Georgia and, likewise, varieties fitting Georgia conditions may not be suitable for Louisiana. This is an important consideration due to the photoperiodic nature of soybean (Board and Settimi, 1986). 51 vegetable soybean cultivars adapted to different ecological regions have been released for the past 20 years in China. Among them, 25 cultivars were selected in South China, 12 cultivars in Central China, 10 cultivars in North China, and 4 cultivars in Northeast China. Still, lack of adapted vegetable soybean cultivars is one of the major factors restraining its commercial production in China, and over 500 vegetable soybean germplasms are available for breeding purpose (Zhang et al., 2013b).

In contrast to early-season responses, vegetable soybean produced smaller plants than grain-type soybean at R6 stage. Varieties with smaller canopy offer advantages for mechanical harvest and modern fresh legume harvesters can be used successfully in vegetable soybean (Mbuvi and Litchfield, 1994). Plant height and height of lowest pod are important considerations for selecting a cultivar for commercial production. If harvesting is done by hand plant size and lowest pod height is not a factor, while the crop is to be mechanically harvested, plant size and lowest pod height will become an important consideration to maintain harvest efficiency. It has been shown that tall plants can have a negative effect on harvest efficiency (Zandonadi et al., 2010). Bright green pods with gray pubescence approximately $5.0 \mathrm{~cm}$ long and $1.4 \mathrm{~cm}$ wide, with two or brighter green seeds having light buff or gray hila, are considered important for fetching high market prices (Shanmugasundaram, 1996; Wu et al., 2000).

Edamame cultivars are often plagued with poor crop establishment in several environments (Rao et al., 2002; Sanchez et al., 2005; Zhang et al., 2013a). Problems with edamame germination have been well documented (Williams et al., 2012; Hamilton, 2007). The reduced emergence in vegetable soybean appeared to be due to lower germination, longer length of hypocotyl and root during emergence as well as to sensitivity to planting depth, which is higher than the grain-type soybeans one (Zhang et al., 2013a).

Sowing depth of 1-inch for vegetable soybean was recommended in Northeastern USA, and differences were found between the first to the last sowing date (from 15 to 30 days) for fresh pod (R6) yield. Seed dry matter accumulation period was extended for one or two more weeks by late sowing. The later the sowing date, the longer the duration from R6 to mature seed harvest in Massachusetts (Zhang et al., 2010). The ideal soil $\mathrm{pH}$ for vegetable soybeans was found to be 6.0 (Miles et al., 2000) and in a field where no legumes have been previously grown, Rhizobia inoculation at the rate of $10 \mathrm{~g} / \mathrm{ka}$ of seed is needed to boost nitrogen-fixing (Lal et al., 2001).

Clearly, methods to improve crop establishment are actually needed for vegetable soybean production, and additional edamame cultivar development through traditional plant breeding integrated with molecular biology is strongly required, which has the potential to greatly improve currently available cultivars (Ogles et al., 2016).

\section{Planting date and fertilisation}

Certain agronomic practices are believed to influence the quality and flavor of vegetable soybean (Duppong and HattermanValenti, 2005). Zhang et al. (2010) proposed that the decline in marketable yield of vegetable soybean by 34 to $55 \mathrm{~kg} \mathrm{ha}^{-1} \mathrm{~d}^{-1}$ with delayed sowing date was mainly related to the decrease in twoseed and three-seed pods. Because delayed planting date involved environment change, cultivars with strong capacity in retaining more two-seeded pods may possess an advantage if planting is 
delayed (Li et al., 2014). Li et al. (2014) further indicated that planting after 15 May increased seed protein content by $4.1 \%$ to $7.5 \%$ and reduced oil content by 2.4 to $26.3 \%$ for different cultivars. The contents of free amino acid, sum of fructose and glucose, raffinose, and stachyose in seed were also increased by late planting. By contrast, late planting reduced the seed sucrose content ranging from 7.6 to $45.5 \%$ for the different cultivars. Planting on 3 May usually produced the greatest fresh pod yield and highest seed sucrose content. These results demonstrated that late planting after early May might have a negative impact on the eating quality of vegetable soybean. Because sucrose is intensely associated with the eating quality of vegetable soybean and the cultivar with higher sucrose level is preferred in the market, the potential negative impact on the eating quality of vegetable soybean induced by delayed planting date deserves more attention.

In Japan, the yielding ability of green soybean in open fields is affected by its sowing time due to adverse weather conditions (low temperature or rainfall). The number of pods set and the green soybean yield tended to decrease with the delay in the sowing time. However, in both early and late sowing, the yield tended to be higher when large quantities of nitrogen topdressing were applied (Nishioka and Okumura, 2008). Nishioka and Okumura (2008) also found that plant top growth during the early growth stages and its dry weight during the flowering stage increased with the increase in the amount of nitrogen applied as basal dressing, but the length of the main stem, number of branches, and total number of nodes at the time of harvesting did not. The yield, number of pods, and proportion of high-quality 3 -grainedpods increased with the amount of nitrogen topdressing.

Optimal fertilisation can maximise yield as well as quality. It was found that the ideal fertilisation for flavor and sweetness was the combination of $50 \%$ chemical fertiliser (N-P-K at 30-40-30 $\mathrm{kg} / \mathrm{ha}$ ) and $50 \%$ chicken manure or fermented pig dung. Miles et al. (2000) found that $40 \mathrm{~kg} / \mathrm{ha} \mathrm{N}$ treatments produced the highest marketable yields, while the $120 \mathrm{~kg} / \mathrm{ha} \mathrm{N}$ treatment produced the fewest number of beans. Li et al. (2014) found that excessive $\mathrm{N}$ application not only reduced the fresh pod yield but also decreased vegetable soybean eating quality. Soil $\mathrm{K}$ fertiliser plus the foliar application of $\mathrm{K}$ increased the content of sucrose and fructose but decreased the protein content and increased the fat content.

These results suggest addition of potassium fertiliser with basal dressing of nitrogen, plus nitrogen and potassium topdressing after the flowering stage, is effective in improving the yield and quality of green soybean, making it possible to raise the value of this commodity and improve the profitability of green soybean cultivation. The influence of applying large quantities of nitrogen top dressing on the subsequent crop deserves further studies.

\section{Weed management and harvesting}

Poor weed control, resulting from limited herbicide availability and undeveloped integrated weed management systems, is a major hurdle to production of vegetable soybean on a commercial scale. Currently, weed management in edamame is characterised by use of crop rotation, rotary hoeing, interrow cultivation, minimal herbicide use, and extensive hand weeding. Hand weeding is the most common form of weed control in East Asian countries, especially in China (Pronprom et al., 2010; Zhang et al., 2013b). In the United States, vegetable processors also rely on hand weeding, labor costs can exceed $\$ 1,200 \mathrm{ha}^{-1}$. Such high production costs threaten specialty crop production because of the economic disadvantage relative to countries where labor costs are low (Fennimore and Doohan, 2008).

Williams (2015) tested ten different weed management treatments in three edamame cultivars over a 3-yrperiod. He found that all weed management treatments increased marketable pod yield relative to the nontreated control, but only treatments with saflufenacil or S-metolachlor combinations were comparable to the handweeded weed-free treatment. Of the treatments studied, S-metolachlor followed by imazamox was among the greatest yielding, had the least weed density and biomass, and did not reduce crop population density. Edamame injury from $70 \mathrm{~g}$ imazamox ha $\mathrm{ha}^{-1}$ applied post emergence was reported by Williams and Nelson (2014), although the level of injury among edamame entries was less than injury among grain-type soybean entries. A significant limitation to treatments using imazamox or imazethapyr is the occurrence of weed populations resistant to ALS-inhibiting herbicides. Globally there are more weed populations resistant to ALSinhibiting herbicides than any other mode of action. In the United States alone, populations of 46 species have documented resistance to ALS-inhibiting herbicides, some of which exhibit resistance to multiple herbicides (Heap, 2014). Managing herbicide resistance requires not only a multifaceted approach, but also landowners and growers having an accurate perception of the effectiveness of current practices and realistic expectation of future technology (Norsworthy et al., 2012). Further research is needed to develop a mechanistic understanding of edamame-weed interactions, including the extent to which edamame can be improved to compete with weeds because cultivars differed in their weed-suppressive ability (Williams, 2015).

Edamame harvesting is time specific, laborious, and time consuming (Mebrahtu and Mullins, 2007). The time of harvest plays an important role, since sucrose increases in the early stages of green soybean growth, peaking at or after around 35 days after flowering (Chiba, 1991; Zhang et al., 2015). There is a narrow window for optimal harvesting, usually around 35-39 days after flowering. After harvest, sugar levels drop swiftly, especially at high temperatures and, therefore, measures should be taken to preserve the high quality of beans by cooling and high humidity storage (Chiba, 1991). The time of harvesting is a critical factor in determining consumer acceptability and marketability of fresh vegetable soybeans (Mbuvi and Litchfield, 1995).

The optimum time for harvesting fresh vegetable soybean and the best product quality with maximum yield are the function of a dynamic relationship between maturity, yield, and quality parameters (Lee, 1989). Quality properties such as color, texture, and seed size of vegetable soybean are a function of development time (Mbuvi and Litchfield, 1995). Since these quality parameters do not peak at the same time, it is necessary to find a compromise about time of harvest of green beans. Shanmugasundaram (1996) reported that the optimum time for harvesting green beans was when the pods are still green, immature, and tight with fully developed immature green seeds. This stage coincides with the R6 stage of soybean development (Fehr and Caviness, 1977). Thus, R6 stage is very critical for ensuring bean yield and quality. Among physical characteristics, appearance as well as size of fresh pods and seeds is important.

Further research should be done to develop rudimentary weed management systems and harvesting machine for edamame production, and maintain superior taste in combination with the other desirable qualities of vegetable soybean. 


\section{Constraints and future research challenges}

The main problem experienced with vegetable soybean farming is the extensive labor at harvest, which increases the demand for genotypes suited to mechanised harvest. Greater distance from the ground to the lowest pod makes mechanical harvest more suitable. The Asian Vegetable Research and Development Center in Taiwan has developed machinery for planting, harvesting, and separation of pods from stems with efficiency around 93\%-95\% (Shanmugasundaram and Yan, 2004). Such machinery may be adapted to all production conditions with little or no modifications.

Further improvements in crop production are necessary, these include: i) to improve crop establishment; ii) to develop cultivars with competitive ability to weed, and resistant to certain insect pests/diseases, which will likely result in more competitive and productive production system.

\section{Conclusions}

Though edamame has been advertised as a miracle super-food for reducing heart disease and cancer risk, there is scant literature on adaptable varieties with known neutraceutical properties and on experiences in organic production, as reported for other crops (Conti et al., 2014, 2015). Therefore, the very urgent research challenges in the future are: i) to assess the elemental and phytochemical properties of edamame and their in vitro biological activities on cancer cell inhibition; ii) to develop an optimised organic production system featuring low costs and high yield for vegetable soybean. These new insights will certainly help to stimulate edamame production and utilisation, and offer potential for expanding the domestic and international soybean market.

\section{References}

Abe T, Kano M, Sasahara T, 2005. Quantitative difference of 7s globulin on vegetable soybean seeds. Nippon Shokuhin Kagaku Kogaku Kaishi 52:107-13.

Adlercreutz H, 2002. Phytoestrogens and breast cancer. J. Steroid Biochem. Mol. Biol. 83:113-8.

Anderson JW, Johnstone BM, Cook-Newell ME, 1995. Metaanalysis of the effects of soy protein intake on serum lipids. New Engl. J. Med. 333:276-82.

Board JE, Settimi JR, 1986. Photoperiod effect before and after flowering on branch development in determinate soybean. Agron. J. 78:995-1002.

Brar GS, Carter TE, 1993. Soybean Glycine max (L.) Merrill. In: Kalloo G. and B.O. Bergh (eds.) Genetic improvement of vegetable crops. Pergamon, Oxford, UK, pp. 427-63.

Butler LM, Wu AH, Wang R, 2010. A vegetable-fruit-soy dietary pattern protests against breast cancer among postmenopausal Singapore Chinese women. Am. J. Clin. Nutr. 91:1013-9.

Carson LC, Freeman JH, Zhou K, Welbaum G, Reiter M, 2011. Cultivar evaluation and lipid and protein contents of Virginiagrown edamame. Hort. Technol. 21:131-5.

Carter TE, Wilson RF, 1998. Soybean quality for human consumption. Soybeans role in Australia. Proc. 10th Australian Soybean Conf. Sept. 15-17, Brisbane, Australia.

Chadha ML, Oluoch MO, 2004. Vegetable soybean research and development in Africa. Available from:
http://203.64.245.61/fulltext_pdf/DOC/20012004/d015165.pdf

Chiba Y, 1991. Postharvest processing, marketing and quality degradation of vegetable soybean in Japan. In: Shanmugasundaram S. (ed.) Vegetable soybean, research needs for production and quality improvement. Proceeding of Workshop, Kenting, Taiwan, Asian Vegetable Research and Development Center. pp.108-12.

Conti S, Villari G, Amico E, Caruso G, 2015. Effects of production system and transplanting time on yield, quality and antioxidant content of organic winter squash (Cucurbita moschata Duch.). Sci. Hortic. 183:136-43.

Conti S, Villari G, Faugno S, Melchionna G, Somma S, Caruso G, 2014. Effects of organic vs. conventional farming system on yield and quality of strawberry grown as an annual or biennial crop in southern Italy. Sci. Hortic. 180:63-71.

Cregan PB, Hartwig EE, 1984. Characterization of flowering response to photoperiod in diverse soybean genotypes. Crop Sci. 24:659-62.

Dong D, Fu X, Yuan F, Chen P, 2014. Genetic diversity and population structure of vegetable soybean (Glycine max (L.) Merr.) in China as revealed by SSR markers. Genet. Res. Crop Evol. 61:173-83.

Duppong LM, Hatterman-Valenti H, 2005. Yield and quality of vegetable soybean cultivars for production in North Dakota. Hort. Technol. 15:896-900.

Fehr WR, Caviness CE, 1977. Stages of soybean development. Iowa State University, Ames, IA, USA.

Fennimore SA, Doohan DJ, 2008. The challenges of specialty crop weed control, future directions. Weed Technol. 22:364-72.

Hara A, Sasazuki S, Inoue M, 2012. Isoflavone intake and risk of gastric cancer: a population based prospective cohort study in Japan. Am. J. Clin. Nutr. 95:147-54.

Hasler CM, 1996. Functional food: The western perspective. Nutr. Rev. 54:506-10.

Heap I, 2014. International survey of herbicide resistant weeds. Available from: http://www.weedscience.org/summary/home. aspx

Johnson D, Wang S, Suzuki A, 1999. Edamame: A vegetable soybean for Colorado. In: J. Janick (ed.) Perspectives on new crops and new uses. ASHS Press, Alexandria, VA, USA. pp. 385-7.

Jouquand C, Chandler C, Plotto A, Goodner K, 2008. A sensory and chemical analysis of fresh strawberries overharvest dates and seasons reveals factors that affect eating quality. J. Am. Soc. Hortic. Sci. 133:859-67.

Keatinge JDH, Easdown WJ, Yang RY, Chadha ML, 2011. Overcoming chronic malnutrition in a future warming world: The key importance of mungbean and vegetable soybean. Euphytica 180:129-41.

Kim JA, Hong SB, Jung WS, Yu CY, Ma KH, Gwag JG, Chung IM, 2007. Comparison of isoflavones composition in seed, embryo, cotyledon and seed coat of cooked-with-rice and vegetable soybean (Glycine max L.) varieties. Food Chem. 102:738-44.

Koes R, Verwejj W, Quattrocchio F, 2005. Flavonoids: a colorful model for the regulation and evolution of biochemical pathways. Trends Plant Sci. 10:236-42.

Kulling SE, Lehmann L, Metzler M, 2002. Oxidative metabolism and genotoxic potential of major isoflavone phytoestrogens. J. Chromatogr. B. 777:211-8.

Lal GS, Lai H, Shanmugasundaram S, 2001. Maps of India. Available from: http://www.mapsofindia.com/indiaagricul- 
ture/oil-seeds/soybean-growing-states.html

Lee CY, 1989. Green peas. In: Eskin M.A.M. (ed.) Quality control in preservation of vegetables. CRS Press Inc., Boca Raton, FL, USA. pp. 159-83.

Lee SJ, Ahn JK, Kim SH, Kim JT, Han SJ, Jung MY, 2003. Variation in isoflavone of soybean cultivars with location and storage duration. J. Agric. Food Chem. 51:3382-9.

Li YS, Du M, Zhang QY, Wang GH, Hashemi M, Liu XB, 2012. Greater differences exist in seed protein, oil, total soluble sugar and sucrose content of vegetable soybean genotypes [Glycine $\max ($ L.) Merrill] in Northeast China. Austral. J. Crop Sci. 6:1681-6.

Li YS, Du M, Zhang QY, Wang GH, Jin J, Herbert SJ, Liu XB, 2014. Planting date influences fresh pod yield and seed chemical compositions of vegetable soybean. Hort. Sci. 49:1-5.

Masuda R, 1991. Quality requirement and improvement of vegetable soybean. In: Shanmugasundaram S. (ed.) Vegetable soybean, research needs for production and quality improvement. Proceeding of Workshop, Kenting, Taiwan, Asian Vegetable Research and Development Center. pp. 92-102.

Masuda, R, 2004. The strategy for sweetness increase of vegetable soybeans: maltose, another sugar in boiled seeds. In: Moscardi F., Hoffmann Campo C.B., Saraiva O.F. (eds.) Proceedings of 7th World Soybean Research Conference/6th International Soybean Processing and Utilization Conference/3rd Brazilian Soybean Congress, Foz do Iguacu, Brazil Feb 29-Mar 05, 2004. pp. 839-44.

Mbuvi SW, Litchfield JB, 1994. Mechanical shelling and combine harvesting of green soybeans. Appl. Engin. Agric. 10:351-5.

Mbuvi SW, Litchfield JB, 1995. Green soybeans as vegetable: Comparing green soybeans with green peas and lima beans, and maximized harvest time determinations using mathematical modeling. J. Veg. Crop Prod. 1:99-121.

Mebrahtu T, Mullins C, 2007. Efficiency of mechanical harvest for immature vegetable soybean pods. Virginia J. Sci. 58:165-74.

Messina M, 2001. An overview of the health effects of soyfoods and soybean isoflavones. In: Lumpkin T.A., Shanmugasundaram S. (eds.) 2nd Int. Vegetable Soybean Conf., Washington State Univ., Pullman, PA, USA. pp. 117-22

Messina M, Wu AH, 2009. Perspectives on the soy-breast cancer relation. Am. J. Clin. Nutr. 89:1673-9.

Miles CA, Lumpkin TA, Zenz L, 2000. Edamame. Farming west of the cascades. Washington State University, Washington, DC, USA.

Mimura M, Coyne CJ, Bambuck MW, Lumpkin TA, 2007. SSR diversity of vegetable soybean [Glycine max (L.)Merr.]. Genet. Res. Crop Evol. 54:497-508.

Mohamed A, Rao MSS, Mebrahtu T, 2001. Nutritional and health benefits of vegetable soybean: Beyond protein and oil. In: Lumpkin T.A. and Shanmugasundaram S. (eds.) 2nd Int. Vegetable Soybean Conf., Washington State University, Pullman, PA, USA. pp. 131-4.

Nishioka H, Okumura T, 2008. Influence of sowing time and nitrogen topdressing at the flowering stage on the yield and pod character of green soybean (Glycine max (L.) Merrill). Plant Prod. Sci. 11:507-13.

Norsworthy JK, Ward SM, Shaw DR, Llewellyn RS, Nichols RL, Webster TM, Bradley KW, Frisvold G, Powles SB, Burgos NR, Witt WW, Barrett M, 2012. Reducing the risks of herbicide resistance: best management practices and recommendations. Weed Sci. Spec. Iss 60:31-62.

Nuss J, 2013. US soybean farmers see growth potential in edamame. Available from: http://newsok.com/article/feed/ 520214
Ogles CZ, Guertal EA, Weaver DB, 2016. Edamame cultivar evaluation in Central Alabama. Agron. J. 108:2371-8.

Pornprom T, Sukcharoenvipharat W, Sansiriphun D, 2010. Weed control with pre-emergence herbicides in vegetable soybean (Glycine max L. Merrill). Crop Protect 29:684-90.

Rao MSS, Bhagsari AS, Mohamed AI, 2002. Fresh green seed yield and seed nutritional traits of vegetable soybean genotypes. Crop Sci. 42:1950-8.

Reuber S, Bornman JF, Weissenbock G, 1996. A flavonoid mutant of barley (Hordeumvulgare L.) exhibits increased sensitivity to UV radiation in the primary leaf. Plant Cell Environ. 19:593601.

Saldivar X, Wang YJ, Chen P, Hou A, 2011. Changes in chemical composition during soybean seed development. Food Chem. 124:1369-75.

Sams CE, Pantalone VR, Kopsell DA, Zivanovic S, Deyton DE, 2012. Edamame: a potential high value crop for growers Proceedings of the Mid-Atlantic Fruit and Vegetable Convention. Mid-Atlantic Fruit and Vegetable Convention, Hershey, PA, USA.

Sanchez E, Kelley K, Butler L, 2005. Edamame production as influenced by seedling emergence and plant population. Hort. Technol. 15:672-6.

Schnitkey G, 2015. Revenue and costs for corn, soybeans, wheat, and double-crop soybeans, actual for 2009 through 2014, projected 2015 and 2016. Department of Agriculture and Consumer Economy, University of Illinois, Champaign, IL, USA.

Setchell KDR, Cassidy A, 1999. Dietary isoflavones: biological effects and relevance for human health. J. Nutr. 129:758-67.

Shanmugasundaram S, 1996. The evolving global vegetable soybean industry. In: Duchanan A. (ed.) Proc. 2nd Int. Soybean Processing and Utilization Conf. Bangkok, Thailand. pp. 472-8.

Shanmugasundaram S, 2001. Global extension and diversification of fresh and frozen vegetable soybean. In: Lumpkin T.A. and Shanmugasundaram S. (eds.) 2nd Int. Vegetable Soybean Conf., Washington State University, Pullman, PA, USA. pp. 161-5.

Shanmugasundaram S, Yan MR, 2004. Global expansion of high value vegetable soybean. The 7th World Soybean Research Conference, pp. 915-20.

Shockley J, Dillon C, Woods T, 2011. Estimating the economic viability of a new crop alternative for the U.S. organic market: edamame - a vegetable soybean. Agricultural and Applied Economics Association's 2011 Meeting, Pittsburgh, PA, USA.

Shurtleff W, Aoyagi A, 2009. History of edamame, green vegetable soybeans, and vegetable-type soybeans (1275-2009): Extensively annotated bibliography and sourcebook. Soy info Center, Lafayette, CA, USA.

Soyfoods, 2014. Sales and trends. Soyfoods Association of North America. Available from: http://www.soyfoods.org/soy-products/sales-and-trends

Tsou SCS, Hong TL, 1991. Research on vegetable soybean quality in Taiwan. In: Shanmugasundaram S. (ed.) Vegetable soybean research needs for production and quality improvement. Proceedings of a workshop held at Kenting, Taiwan 29 April 2 May 1991, pp. 103-7.

Velasquez MT, Bhathena SJ, 2007. Role of dietary soy protein in obesity. Int. J. Med. Sci. 4:72-82.

Williams M, Herman T, Nelson R, 2012. Edamame Cultivar Report-2011. Midwestern Vegetable Variety Trial Report for 2011. Purdue University, West Lafayette, IN, USA.

Williams MM II, 2015. Managing weeds in commercial edamame 
production: Current Options and Implications. Weed Sci. 63:954-61.

Williams MM II, Nelson RL, 2014. Vegetable soybean tolerance to bentazon, fomesafen, imazamox, linuron, and sulfentrazone. Weed Technol. 28:601-7.

Wu QL, Wang MF, Sciarappa WJ, Simon JE, 2004. LC/UV/ESIMS analysis of isoflavones in edamame and tofu soybeans. J. Agric. Food Chem. 52:2763-9.

Wu TL, Tang N, Zhao ZS, 2000. Selection standards of seed and pod characteristics for vegetable soybean. Soybean Sci. 19:184-7.

Xu YX, Barbaro J, Reese F, Langaigne A, Rutto L, Kering M, 2015. Physicochemical, functional and microstructural characteristics of vegetable soybean (Glycine max) as affected by variety and cooking process. J. Food Meas. Charact. 9:471-8.

Yoshiki Y, Kudou S, Okubo K, 1998. Relationship between chemical structure and biological activities of triterpenoid saponin from soybean. Biosci. Biotechnol. Biochem. 62:2291-9.

Zandonadi R, Coolong T, Pfeiffer T, 2010. Mechanical harvesting of edamame. Available from. https://www.uky.edu/Ag/CCD/ edamameharvest.pdf
Zhang L, Kyei-Boahen S, 2007. Growth and yield of vegetable soybean (edamame) in Mississippi. Hort. Technol. 17:26-31.

Zhang QY, Gao QL, Herbert SJ, Li YS, Hashemi AM, 2010. Influence of sowing date on phenological stages, seed growth and marketable yield of four vegetable soybean cultivars in Northeastern USA. Afr. J. Agric. Res. 5:2556-62.

Zhang QY, Hashemi M, Herbert SJ, Li YS, Liu XB, 2013a. Different responses of pre-emergence and early seedling growth to planting depth between vegetable soybean and grain soybeans. Legume Res. 36:515-21.

Zhang QY, Li YS, Liu XB, 2013b. Breeding and physiological research of vegetable soybean in China. Proceedings of 9th World Soybean Research Conference, Durban, South Africa, Feb 17-22, 2013.

Zhang QY, Li YS, Liu XB, 2015. Edible quality and its regulation in vegetable soybean (Glycine max (L.) Merr.). 2015 ASA, CSSA, SSSA International Annual Meetings Nov. 15-18, 2015, Minneapolis, MN, USA.

Zhang YM, Zhao JM, Wang MJ, Xing H, Gai JY, 2006. Genetic variance of nutritional quality of vegetable soybean germplasm in southern China. Soybean Sci. 3:239-43. 